\title{
MEMAHAMI KISAH PENCIPTAAN MANUSIA DAN ALAM SEMESTA: Sebuah Pendekatan Literer Terhadap Kejadian 1-2
}

\author{
Heri Lim*
}

\begin{abstract}
Abstrak: Teks Alkitab dibuka dengan sebuah narasi tentang penciptaan, sebuah teks yang menggambarkan keagungan Allah, sekaligus juga menjadi sebuah topik diskusi di dalam dan di luar kekristenan. Dalam pandangan kekristenan, berbagai penafsiran berbeda disodorkan untuk menjelaskan narasi penciptaan manusia dan kosmos. Artikel ini mencoba untuk menawarkan sebuah sudut pandang yang diharapkan dapat berdialog dengan penafsiran yang lain, tetapi tetap tidak meninggalkan kesetiaan Injili. Artikel ini bukan merupakan eksegesis ayat per ayat kitab Kejadian 1-2, tetapi lebih merupakan sebuah cara untuk memahami narasi penciptaan dalam Kejadian 1-2 secara utuh. Dalam hal ini penulis mencoba untuk mengajukan sebuah pendekatan literer dalam membaca dan memahami narasi penciptaan dalam Kejadian 1-2.
\end{abstract}

Abstract: The biblical text is opened with a narrative about creation. a text that illustrates the majesty of God, as well as becomes topic of discussion within and outside Christianity. In the Christian poin of view, many interpretations are offered to explain the narrative of the human and the cosmos creation. This article tries to offer a perspective that is expected to make a dialogue with other interpretations, but still does not leave evangelical commitment. This article is not a verse by verse exegesis of Genesis 1-2, but rather a way to understand the creation narrative in Genesis 1-2 as a whole. In this case the writer tries to propose a literary approach in reading and understanding the narrative of creation narrative in Genesis 1-2.

Kata-kata kunci: Kejadian, Penciptaan, Genre, Literer, Literal, Figuratif, Narasi, Sejarah, Historisitas, ANE.

* Penulis adalah alumni program M.Div. di STT Amanat Agung. Melayani sebagai Gembala di GKRI Agape Tegal Alur. Penulis dapat dihubungi melalui email: heri.lim.gkri@gmail.com. 


\section{Pendahuluan}

Di tengah zaman yang semakin canggih, narasi penciptaan dalam Alkitab sering kali dianggap berbenturan dengan kacamata pembaca masa kini. Beberapa tahun yang lalu, Peter Enns dalam bukunya The Evolution of Adam, meragukan reliabilitas narasi dari kitab Kejadian, melalui pernyataannya, "In the span of about twenty years, three independent, technical, and powerful forces [science, biblical criticism and biblical archaeology] converged to challenge the historical reliability of Genesis." ${ }^{1} \mathrm{Hal}$ ini merupakan salah satu tantangan dalam kekristenan, khususnya ketika harus menghadapi isu-isu kontroversi di antara teks Alkitab dan sains yang menjelaskan tentang awal mula alam semesta, maupun manusia. ${ }^{2}$

Kendati pun topik tentang narasi penciptaan bukan sesuatu yang baru, ketertarikan para teolog Injili pada hal ini masih cukup besar. Hal ini ditunjukkan melalui adanya pertemuan para teolog biblika dalam simposium di musim gugur 2011, yang diselenggarakan oleh Bryan Institute dengan tajuk "Reading Genesis 1-2." ${ }^{3}$ Berbagai pendekatan biblika pun disodorkan untuk menyelesaikan perdebatan mengenai narasi penciptaan manusia dan alam semesta. Pada dasarnya ada dua ekstrim dalam kubu Injili dalam memahami narasi penciptaan, yakni pendekatan literal atau literer. Kemudian dari

1. Peter Enns, The Evolution of Adam: What the Bible Does and Doesn't Say about Human Origins (Grand Rapids: Brazos, 2012), 3.

2. Marcus J. Borg, The Heart of Christianity: Rediscovering A Life of Faith (San Francisco: Harper Collins, 2003), 53.

3. Charles, J. Daryl, ed. Reading Genesis 1-2: An Evangelical Conversation (Peabody: Hendrickson, 2013), xxi. 
kedua ekstrim inilah akan muncul pendekatan lain dengan berbagai variasi. ${ }^{4}$ Simposium ini pada akhirnya mencoba melihat dua ekstrim dan berbagai variasinya sebagai sebuah kekayaan khazanah biblika, walaupun memang diakui, belum ada titik temu. Penulis melihat bahwa perdebatan ini belum berakhir dan masih menyisakan kebingungan bagi para pembaca. Bagaimanakah seorang pembaca masa kini seharusnya memahami kisah penciptaan dalam Kejadian 12 ?

Pertanyaan ini juga masih relevan bagi para pembaca teks Kejadian 1-2 dalam konteks di Indonesia. Tradisi narasi nampaknya cukup dekat dengan budaya ketimuran, khususnya budaya di

4. Beberapa tokoh biblika memberikan pendekatan yang beragam untuk dapat memahami kisah penciptaan dalam Kejadian 1-2. Todd S. Beall dikenal sebagai salah seorang yang kuat memegang pandangan tradisional dengan penafsiran literalnya. Todd S. Beall, Coming to Grips with Genesis, ed. Terry Mortenson dan Thane H. Ury (Green Forest, AR: Master Books, 2008). Beberapa pakar yang lain menggunakan pendekatan yang cukup berbeda dari pandangan tradisional. Richard Averbeck menganjurkan penafsiran 'skematis' dari kitab Kejadian yang agak mirip dengan framework hypothesis dari C. John Collins tentang "analogical days." Richard E. Averbeck, Giving the Sense: Understanding and Using Old Testament Historical Texts. ed. David M. Howard dan Michael A. Grisanti (Grand Rapids: Kregel, 2003); band. dengan C. John Collins, Genesis 1-4: A Linguistic, Literary, and Theological Commentary (Phillipsburg: P \& R, 2006). Tremper Longman III adalah salah seorang pakar yang cukup kuat dengan penafsiran figurative dalam memahami kitab Kejadian 1-2 dan John Walton memberi penekanan bukan pada sifat 'material' penciptaan, tetapi pada pengertian 'fungsional' dari penciptaan dengan mempertimbangkan konteks Ancient Near East (ANE). John H. Walton, The Lost World of Genesis One: Ancient Cosmology and the Origins Debate (Downers Grove: IVP Academic, 2009); band. Tremper Longman III, How to Read Genesis (Downers Grove: InterVarsity, 2005). 
Indonesia. Indonesia adalah negeri yang kaya akan 'narasi,' sehingga narasi tentang penciptaan dapat menjadi suatu topik yang menarik untuk diulas. ${ }^{5}$ Situasi ini nampaknya dapat menjadi peluang bagi dunia narasi dan pendekatan literer untuk dapat menjadi salah satu studi yang dapat diminati dalam konteks di Indonesia. Pada sisi yang lain, kedekatan tradisi narasi juga perlu dicermati secara hati-hati, karena pemahaman narasi dalam tradisi Indonesia sering kali bersifat mitos, sehingga kesungguhan historisitasnya pun dipertanyakan.

Adapun artikel ini berpandangan bahwa pendekatan literer dapat digunakan oleh para pembaca masa kini untuk dapat memahami narasi penciptaan dalam Kejadian 1-2. Studi atas narasi penciptaan perlu dilakukan untuk membawa pembacanya memahami apa yang diajarkan atau ditekankan dalam Alkitab dan apa yang tidak ditekankan. Berdasarkan pendekatan literer ini didapati sebuah tesis bahwa penekanan utama dari teks tersebut adalah untuk memproklamasikan Yahweh, Allah Israel yang menciptakan manusia dan isi dunia. Alkitab tidak memberi penekanan kepada bagaimana proses Allah mencipta manusia dan kosmos. Oleh karenanya alih-alih membandingkan relasi di antara Alkitab dan sains, penulis mencoba untuk mengajukan sebuah pendekatan literer dalam membaca dan memahami narasi penciptaan dalam Kejadian 1-2, sehingga pembaca dapat memahami

5. Kekayaan narasi di Indonesia dapat dilihat dari banyaknya legenda yang ada. Legenda dipahami sebagai cerita rakyat pada zaman dahulu yang terkait dengan peristiwa sejarah. 
apa yang ditekankan dalam narasi tersebut.

Pendekatan literer yang dimaksudkan di sini merupakan salah satu penafsiran yang menerima bentuk final teks Alkitab (kanon) sebagai sesuatu yang otoritatif dan mencoba mengeksplorasi kekayaan sastranya yang terkandung di dalamnya, seperti: klasifikasi genre, analisis struktur dan pesan teks yang diberikan penulis teks kepada pembacanya. ${ }^{6}$ Pendekatan literer yang diajukan dalam artikel ini, diharapkan dapat mengurangi atau menyelesaikan kebingungan para pembaca teks Kejadian 1-2 dalam memahami narasi penciptaan manusia dan kosmos.

\section{Mencermati Genre}

Alkitab adalah perkataan Allah kepada manusia yang memiliki koherensi dalam pesan-Nya, walaupun dapat berbeda-beda dalam cara pengomunikasiannya. Firman Allah adalah sebuah kumpulan kitab dengan berbagai macam latar belakang penulisnya. Firman Allah dituliskan dalam berbagai periode panjang lebih dari seribu tahun, yang menggunakan beraneka ragam tipe atau jenis sastra kuno tertentu, atau juga disebut sebagai genre. Dalam pembacaan Alkitab akan ditemui berbagai genre di dalamnya, seperti: narasi, puisi, hikmat, hukum, nubuatan, injil, surat (epistle), apokaliptik dan seterusnya. ${ }^{7} \mathrm{Hal}$ ini penting untuk diperhatikan dalam menafsirkan

6. Mark Allan Powell, What is Narrative Criticism? (Minneapolis: Fortress, 1990), 11.

7. Gordon D. Fee dan Douglas Stuart, How to Read The Bible for All Its Worth (Grand Rapids: Zondervan, 2003), 22. Band. dengan Tremper 
suatu bagian teks Alkitab, yakni pencermatan atas genrenya.

Penentuan genre teks Alkitab akan sangat memberi pengaruh besar dalam strategi membaca dan memahami Alkitab. Genre itu yang menjadi alat untuk mengkomunikasikan maksud dari penulis teks Alkitab. Genre dapat menjadi seperti 'kode' bagi pembaca teks, bagaimana sebaiknya menangkap pesan dari penulisnya. Oleh karenanya penting bagi seorang pembaca Alkitab untuk mengenali genre dari teks itu.

Dalam hal ini pembaca dapat mengidentifikasi genre teks Alkitab melalui pencermatan ciri khas teks tersebut.

Dalam penentuan genre apa yang tepat untuk melihat teks Kejadian 1-2, maka adalah penting untuk memperhatikan ciri khas dari teks itu. Kejadian 1-2 perlu dilihat sebagai suatu sastra kuno, sebagaimana Coats menyebut narasi ini sebagai "ancient literary art." ${ }^{8}$ Walaupun demikian penulis juga tidak setuju dengan apa yang diajukan oleh Gunkel dalam melihat kitab Kejadian hanya sebagai sebuah legenda kuno. ${ }^{9}$ Pada sisi yang lain, pandangan Brueggemann yang melihat Kejadian (khususnya pasal 1 ) dengan genre puisi ${ }^{10}$ atau

Longman III, Reading the Bible with Heart and Mind (Colorado: NavPress, 1997), 8.

8. George W. Coats, Genesis with an Introduction to Narrative Literature (Grand Rapids: Eerdmans. 1983), 3.

9. Hermann Gunkel, The Legends of Genesis (Eugene: Wipf \& Stock, 2003), 37-38. Dalam hal ini Gunkel melihat bahwa kisah penciptaan tidak lebih dari sekedar legenda yang dipercaya orang Israel sebagaimana orang ANE mempercayai legenda mereka.

10. Walter Brueggemann, Genesis: A Bible Commentary for Teaching and Preaching (Atlanta: John Knox, 1982), 26-28. Pandangan serupa juga 
Wenham yang menyebutnya sebagai Hymn yang ditulis dengan puisi sastra tinggi, ${ }^{11}$ nampaknya masih dapat diterima mengingat bahasa figuratif yang indah dan agung terdapat di dalamnya.

Kendati demikian penulis lebih cenderung melihat Kejadian 12 dengan genre narasi, sehingga hal ini akan memberi pengaruh bagi penulis dalam melakukan pendekatan literer atas teks tersebut. Penulis melihat bahwa pendekatan literer dapat memberi keuntungan bagi pembacanya untuk tidak terjebak dalam memperdebatkan apa yang tidak ditekankan dalam narasi. Pada sisi yang lain, pendekatan literer menolong pembaca masa kini untuk dapat mengelaborasi kekayaan sastra yang terkandung di dalam narasi tersebut. Oleh karenanya, dalam kerangka artikel ini akan dijabarkan kekayaan sastra mengenai intensitas penggunaan bahasa figuratif, urutan berbeda dari narasi penciptaan Kejadian 1-2 dan pesan apa yang ditekankan dari narasi penciptaan tersebut.

\section{Figuratif Versus Literal dalam Kejadian 1-2}

Longman dan Walton melihat bahwa narasi teks ini (Kejadian 1-2) begitu kuat menggunakan bahasa figuratif. ${ }^{12}$ Hal ini sekaligus

diberikan oleh Bill Arnold, Encountering the Book of Genesis (Grand Rapids: Baker, 1998), 23.

11. Gordon Wenham, Genesis 1-15, WBC 1 (Waco: Word, 1987), 10. Tetapi Wenham menekankan juga bahwa jenis puisi ini berbeda dengan puisi orang ANE. Dalam hal ini Wenham menyatakan Kejadian 1 sebagai "elevated prose, not pure poetry"

12. Tremper Longman III, "Literary Approach to Biblical Interpretation, dalam Foundations of Contemporary Interpretation, ed. Moises Silva (Grand Rapids: Zondervan, 1996), 141-45. Longman III, Reading 
juga memberi petunjuk kepada pembaca untuk melihat kisah ini bukan secara harfiah. Pada sisi yang lain, beberapa pandangan dalam kekristenan melihat bahwa Kejadian 1-2 harus dibaca secara harfiah. Beall dalam hal ini menyatakan bahwa: ${ }^{13}$

There are four possible approaches to Gen 1-11: (1) myth, with little or no historicity; (2) largely figurative, but not myth; (3) partly figurative (neither myth nor entirely literal); and (4) literal. Only views 1 and 4 apply a consistent hermeneutic throughout Genesis.

Pada sisi yang lain, pendekatan keempat memiliki keterbatasan ketika harus melihat kisah itu secara literal, namun berlawanan dengan bagian lain dari Alkitab dan bahkan berlawanan dengan pemahaman tentang Allah. Contoh yang paling jelas adalah pemahaman tentang "hari" secara harfiah dalam narasi penciptaan. Kejadian 1:1-2:4a merupakan bagian narasi penciptaan pertama yang menggambarkan penciptaan dunia dan manusia.

Pada satu sisi, penulis narasi seperti ingin pembacanya memahami "hari" secara literal, yakni sebagaimana dipahami pada orang Yahudi umumnya. Hal ini juga semakin kuat dengan pengulangan bagian akhir dalam setiap hari penciptaan dengan klausa, "jadilah petang dan jadilah pagi" (Kej. 1:5, 8, 13, 19, 23, 31). Pada sisi yang lain ketika narasi ini dicermati, matahari, bulan dan

the Bible with Heart and Mind. John H. Walton, Genesis 1 as Ancient Cosmology (Winona Lake: Eisenbrauns, 2011), 78-84

13. Beall, "Contemporary Hermeneutical Approaches to Genesis 111", 132. 
bintang absen hingga hari yang keempat. Hal ini juga menunjukkan bahwa penggambaran penciptaan selama "satu minggu," tidak harus dipahami sebagai sesuatu yang harfiah terjadi. Dalam hal ini pun Cunningham berkata: ${ }^{14}$

To what person of intelligence, I ask, will the account seem logically consistent that says there was a first day and a second day and a third day in which also evening and morning are named, without sun, without moon and without stars and even in the case of the first day without heaven?

Argumentasi yang biasanya diberikan untuk menjawab masalah ini adalah bahwa terang itu dapat muncul dari Allah secara langsung, sebagai sumber terang. ${ }^{15}$ Tentu saja kemahakuasaan-Nya tidak dapat dibatasi dan Allah dapat menyediakan terang dan gelap dengan cara yang lain dalam dua puluh empat jam itu. Walaupun demikian hal ini juga tidak dapat diartikan bahwa, "jadilah petang dan jadilah pagi" secara literal, sebagaimana dipahami sebagai waktu dari matahari yang terbit di pagi hari, tenggelam pada sore hari dan digantikan oleh pergerakan benda-benda langit pada malam hari. Para penafsir Injili sebenarnya menyadari permasalahan tentang "hari" dalam penciptaan. Averbeck lebih melihat enam hari Allah

14. Conor Cunningham, Darwin's Pious Idea: Why the Ultra-Darwinist and Creationists Both Get It Wrong (Grand Rapids: Eerdmans, 2010), 381. Band. juga Kenneth J. Howell, Natural and Scripture in the Abrahamic Religion: Up to1700, vol. 1 ed. J. Van Der Meer dan S. Mandelbrote (Leiden: Brill, 2008), 123.

15. Beall, "Contemporary Hermeneutical Approaches to Genesis 1$11^{\prime \prime}, 155-56$. 
mencipta dan hari ketujuh Allah beristirahat bukan secara literal, tetapi sebagai suatu cara sastra dengan pola tertentu sebagaimana pola narasi penciptaan bangsa Ancient Near East (ANE). Dalam hal ini Averbeck memberikan pendapat:

Although the seven days are not to be taken literally and are not intended to tell us how long God took in actually creating the cosmos or how old the earth is, nevertheless there is a necessary structure and sequence through the six days. We and the other creatures could not survive without the combined environment of light, water, land, and plants (see the first three days).This is the cosmic framework within which we live. It is observable and basic. The ANE sources reflect this, and Gen 1 arranges things according to the same pattern. ${ }^{16}$

Penulis juga melihat bahwa narasi penciptaan yang digambarkan selama enam hari dan pada hari ketujuh Allah beristirahat, penekanannya bukan pada urutan hari yang harus dilihat secara harfiah, tetapi dilihat sebagai sebuah karya sastra agung yang memberi suatu pesan tertentu. Demikian hal ini terlihat pada hari pertama hingga ketiga yang menggambarkan penciptaan alam semesta. Pada sisi yang lain, hari keempat hingga keenam adalah menggambarkan pemenuhan alam semesta itu dengan penghuni-penghuni yang Allah jadikan. Pola sastra enam hari

16. Richard E. Averbeck, Giving the Sense: Understanding and Using Old Testament Historical Text, ed. David Howard, Jr. dan Michael A. Grisanti (Grand Rapids: Kregel, 2003), 113. 
penciptaan (forming and filling) dapat dilihat sebagai berikut: ${ }^{17}$

\section{Days of Forming}

Day 1- "Let there be light" (1:3).

Day 2 - "Let there be an expanse in the midst of the water, and let it separate the waters from the waters" (1:6).

Day 3 - "Let dry ground appear" (1:9).

"Let the land produce vegetation" (1:11).

\section{Days of Filling}

Day 4 - "Let there be lights" (1:14).

Day 5 - "Let the waters teem with swarms of living creatures, and let birds fly above the earth in the open expanse of the heavens" (1:20).

Day 6 - "Let the earth bring forth living creatures" (1:24). "Let us make man" (1:26). "Behold, I have given you every plant yielding seed that is on the surface of all the earth, and every tree which has fruit yielding seed, it shall be food for you" (1:29).

Contoh lain penggunaan bahasa figuratif adalah dalam narasi penciptaan Kejadian 2:4a-25. Dalam hal ini narasi menggambarkan penciptaan laki-laki dan perempuan pertama, dengan gaya bahasa anthropomorphic. ${ }^{18}$ Allah mencipta Adam dari tanah, di mana Kejadian 2:7 berkata, "ketika itulah TUHAN Allah membentuk manusia itu dari debu tanah dan menghembuskan nafas hidup ke dalam hidungnya; demikianlah manusia itu menjadi makhluk yang

17. Claus Westermann, Genesis 1-11: A Commentary (Minneapolis: Augsburg, 1984-86), 80; band.: https://zondervanacademic.com/blog/ genesis-1/ diakses 25 Februari 2019.

18. Henri Blocher, In the Beginning: The Opening Chapters of Genesis (Leicester: InterVarsity, 1984), 50. Anthropomorphic dapat diartikan sebagai pengenaan atau penyamaan pada Allah bentuk-bentuk atau perilaku manusiawi. Kata anthropomorfisme merupakan salah satu gaya bahasa untuk menggambarkan bahwa Tuhan memiliki bentuk dan sikap yang sama dengan manusia. 
hidup." Penggambaran ini dapat dikaitkan dengan kisah penciptaan orang Ancient Near East (ANE) yang menggambarkan Allah seperti manusia yang memiliki tubuh seperti manusia, ${ }^{19}$ memiliki paru-paru sehingga dapat menghembuskan nafas kepada manusia. Tentu saja karena Allah adalah Roh adanya, narasi tersebut menggunakan gaya bahasa anthropomorphic, sehingga narasi penciptaan Adam perlu dilihat secara figuratif.

Pada sisi yang lain, bahasa figuratif di sini juga tidak bermaksud mereduksi historisitas narasi, khususnya historisitas Adam di dalamnya. Walaupun demikian tidak dapat dipungkiri beberapa tokoh Injili yang menggunakan pendekatan naratif biasanya akan melihat historisitas Adam bukan sebagai suatu keharusan. ${ }^{20}$ Longman III misalnya, melihat bahwa, "my understanding of Gen. 1-2 as high style literary prose narrative leads me to conclude that it is not necessary that Adam be a historical individual for this text to be without error in what it intends to teach." 21 Demikian pula Walton melihat penekanan penciptaan tokoh Adam dan Hawa dalam narasi ini bukan kepada historisitasnya, tetapi kepada "function and

19. Band. W.W Hallo dan K. Lawson Younger Jr., The Context of Scripture, 3 vol (Leiden: Brill, 1997, 2000, 2002); Markham J. Geller dan Mineke Schipper, Imagining Creation (Leiden: Brill, 2008); Kenton L Sparks, Ancient Text for the Study of the Hebrew Bible (Peabody: Hendrikson, 2005) 305-22; dan John H. Walton, Genesis 1 as Ancient Cosmology.

20. C. John Collins, Did Adam and Eve Really exist? Who They Were and Why You Should Care (Wheaton: Crossway 2011), 53-54.

21. Tremper Longman III, Foundations of Contemporary Interpretation (Grand Rapids: Zondervan, 1996), 145. 
archetypal representation" 22 bagi umat manusia.

Bagaimana seharusnya orang Injili melihat hal ini? Penulis melihat bahwa pendekatan naratif tidak harus menegasikan historisitas Adam sebagaimana dipahami di atas. Pencermatan atas narasi ini justru memberikan pertimbangan historis dalam melihat Adam dan Hawa sebagai nenek moyang historis bagi umat manusia. Pencermatan unsur narasi, di mana penulis Kejadian memberikan latar tempat yang memang historis patut untuk diperhatikan. Dalam hal ini Averbeck juga menyatakan:

In this particular account, however, we have a more standard literary narrative with historical markers. For example, the Tigris and especially the Euphrates rivers were known to the Isrealites of Moses' day by name and general location (Gen 2:14), and in my opinion Adam and Eve are viewed as actual historical individuals (see also 5:1-3, etc). ${ }^{23}$

Selanjutnya genealogy yang dicatat dalam Kejadian 5:1-5, 1 Tawarikh 1:1, Lukas 3:38 dan Roma 5:12-21 juga mengindikasikan historisitas

22. John H. Walton, The Lost World of Adam and Eve: Genesis 2-3 and the Human Origins Debate (Illinois: IVP Academic, 2015), 61. Dalam hal ini Walton menyatakan hal berikut: "The reference of materials (dust, rib) and the use of verbs that have been interpreted as material activities must be addressed. I propose that rather than interpreting this account as offering a material of human origins, it offers functional account founded on the concept of archetypal representation." Hal ini pun digambarkan dalam Kejadian 3:19, bahwa semua umat manusia berasal dari debu dan akan kembali kepada debu. Hawa sebagai ibu dari segala yang hidup pun juga dalam hal ini dapat dilihat archetypally, di mana ia menggambarkan fungsi wanita di bumi yang diberi kemampuan khusus untuk dapat meneruskan kehidupan melalui rahim yang Allah berikan.

23. Averbeck, Giving the Sense, 117. 
Adam yang sulit untuk ditiadakan. ${ }^{24}$ Akan sulit untuk dipahami jika Adam hanya dilihat sekadar tokoh 'literer' yang tidak memiliki historisitas. Bagaimana mungkin seseorang dapat menerima genealogy dan toledot dari Adam dan keturunannya hingga kepada Kristus, jika tidak melihatnya sebagai tokoh yang historis. ${ }^{25}$ Jadi adalah hal yang sulit untuk dapat menerima narasi itu sebagai sekadar fenomena literasi semata atau sebagai sebuah nilai teologis yang dibangun bukan atas fakta sejarah.

Argumentasi berikutnya dalam mempertimbangan historisitas Adam adalah dengan memperhatikan penggunaan waw-consecutive berdasarkan kacamata "Hebrew historical narrative." ${ }^{26}$ Wawconsecutive muncul 55 kali dalam Kejadian 1: 1-2: 3, sedangkan dalam Kejadian 2:4-25 muncul 21 kali. ${ }^{27}$ Penggunaan wawconsecutive secara konsisten dalam narasi juga ditemukan dalam bagian selanjutnya dalam kitab Kejadian, di mana total kemunculan waw-consecutive dalam kitab ini adalah 2107 kali. ${ }^{28}$ Narasi dalam

24. Victor P. Hamilton, The Book of Genesis: Chapters 1-17, NICOT, (Grand Rapids: Eerdmans, 1990), 2-8; Gordon Wenham, Genesis 1-15, WBC 1 (Waco: Word, 1987), xxii. Band. Walter C. Kaiser Jr., "The Literary Form of Genesis 1-11," dalam New Perspectives on the Old Testament, ed. J. Barton Payne (Waco: Word, 1970), 61.

25. C. John Collins, Did Adam and Eve Really Exist?: Who They Were and Why You Should Care (Wheaton: Crossway 2011), 19.

26. Bill T. Arnold dan John H. Choi, A Guide to Biblical Hebrew Syntax (Cambridge: Cambridge University Press, 2003), 84.

27. Robert V. McCabe, "A Critique of the Framework Interpretation of the Creation Week" dalam Coming to Grips with Genesis, ed. Thery Mortenson dan Thane H. Ury (Green Forest: Master Books, 2012), 216.

28. McCabe, "A Critique of the Framework," 217. 
kitab Kejadian terhubung dengan waw-consecutive yang menunjukkan adanya kelanjutan kisah antara bagian sebelumnya dan sesudahnya dari narasi tersebut. Kaiser dalam hal ini melihat adanya kontinuitas ini sebagai sebuah "consecutive history." 29

Konsekuensi logis dari adanya consecutive history dalam bagian ini adalah melihat tokoh-tokoh itu sebagai bagian historis yang terkait satu dengan lainnya. Tidaklah mungkin Abraham dianggap sebagai karakter historis, sedangkan Terah, ayahnya, tidak sungguh-sungguh ada dalam sejarah. Demikian pula tidaklah mungkin Terah dapat dianggap sebagai karakter historis, jika Nahor, Serug, Sem, Nuh dan semua karakter yang lainnya hingga kepada Adam bukan tokoh yang sungguh ada dalam sejarah. Adanya consecutive history mengimplikasikan bahwa, adalah tidak logis untuk melihat suatu bagian tertentu dalam unit narasi tersebut sebagai kisah yang kurang historis daripada bagian yang lain.

Oleh karena itu keterkaitan Kejadian 1-2 dengan unit narasi lain dalam bagian berikutnya dalam kitab Kejadian menjadi sesuatu kontinuitas yang perlu untuk dicermati. ${ }^{30}$ Kontinuitas Kejadian 1-2 dan narasi dalam pasal berikutnya dari kitab Kejadian memberi argumentasi kuat kepada penekanan sejarah (historical impulse). Kendati begitu banyak bahasa figuratif terdapat dalam narasi

29. Walter C. Kaiser Jr., The Old Testament Documents: Are They Reliable and Relevant? (Downers Grove: InterVarsity, 2001), 88.

30. Wilhelm Gesenius, Gesenius' Hebrew Grammar, ed. ke-2 bahasa Inggris (Oxford: Clarendon, 1910), 326. Gesenius dalam hal ini melihat Wawconsecutive mengindikasikan adanya "logical sequel of actions, events or state mentioned immediately before." 
penciptaan, hal ini bukan untuk menunjukkan Adam hanya sekadar tokoh figuratif. Bahasa figuratif hanyalah alat untuk menyampaikan Adam yang sungguh historis. Sailhamer juga mengakui historisitas ini dengan mengungkapkan, "the account of those events and persons exhibits all the traits of historical trustworthiness." ${ }^{31}$

\section{Perbedaan Urutan Kronologis Narasi Penciptaan}

Pembaca yang cermat akan menemukan adanya dua bentuk kisah penciptaan yang berbeda dalam narasi Kejadian 1-2. Bagian pertama dapat ditemukan dalam Kejadian 1:1-2:4a dan bagian kedua dapat ditemukan dalam Kejadian 2:4b-25. Ada perdebatan panjang tentang apakah formula toledoth (iֹתרתוֹ) dalam teks Kejadian 2:4a ${ }^{32}$ tersebut mengakhiri bagian Kejadian 1:1-2:4a atau mengawali Kejadian 2:4b-25. Artikel ini tidak memperdebatkan hal itu. Dalam pembacaan di zaman sekarang, nampaknya dua bentuk pengisahan berbeda menjadi sesuatu yang kurang lazim, namun ketika mencermati seluruh bagian Alkitab, pembaca akan menemukan hal yang serupa. Demikian pula dalamcatatan sejarah Israel yang ditulis dalam kitab Samuel, Raja-Raja dan Tawarikh, kadang pembaca dapat melihat beberapa pengisahan untuk satu peristiwa yang sama, walaupun perspektif narasinya berbeda. Oleh karenanya adalah tidak terlalu mengejutkan ketika kitab Kejadian membuka narasinya

31. John Sailhamer, The Pentateuch as Narrative (Grand Rapids: Zondervan, 1992), 23-24.

32. Dalam hal ini dikatakan, "demikianlah riwayat (toledoth) langit dan bumi pada waktu diciptakan." 
dengan 'dua' kisah penciptaan seperti itu.

Hal yang ditekankan dari kedua bagian teks penciptaan itu adalah bahwa kedua narasi itu memiliki perspektif masing-masing yang unik tentang penciptaan. Bagian narasi pertama dapat dilihat dalam perspektif kosmos, di mana Allah mencipta alam semesta dan segala isinya. Penciptaan manusia dalam hal ini terkait kuat dengan penciptaan yang lebih besar, yaitu penciptaan alam semesta yang akan ditempati oleh manusia. Pada bagian narasi kedua, perspektifnya lebih difokuskan kepada penciptaan manusia itu sendiri. Kedua narasi tersebut (Kej. 1:1-2:4a dan Kej. 2:4b-25) tetap memiliki perbedaan, khususnya mengenai urutan kisah penciptaannya. Walton pun juga menyadari realita akan hal ini, dengan menyatakan:

Over the generation of interpreters, a common perception has been that there is conflict between the two accounts, not only in focus but also in sequence. This perception has led some to tinker with some alternative translations of verbal forms (e.g., Gen 2:19 in NIV: "the Lord God had formed out of the ground all the wild animals" and led others to identify the two accounts as coming from different sources whose differences had not been reconciled. ${ }^{33}$

Pengulasan tentang "hari" yang sangat sulit untuk dilihat secara harfiah, telah dipaparkan sebelumnya dalam bagian penggunaan bahasa figuratif di atas. Dalam bagian ini pun, pemahaman 'hari' secara harfiah akan berbenturan ketika seseorang

33. Walton, Genesis 1 as Ancient Cosmology, 142. 
mencermatinya. Jika pembaca mempertahankan pemahaman harfiah dari Kejadian 1:1-2:4a bahwa manusia dicipta pada hari keenam setelah penciptaan tumbuhan, maka dalam bagian narasi ini (Kej. 2:4b-7), pemahaman itu akan berbenturan. Bagian kedua dari narasi itu dengan tegas menyebutkan bahwa: ${ }^{34}$

${ }^{4 b}$ Ketika TUHAN Allah menjadikan langit dan bumi,- ${ }^{5}$ belum ada semak apapun di bumi, belum timbul tumbuhantumbuhan apapun di padang sebab TUHAN Allah belum menurunkan hujan ke bumi, dan belum ada orang untuk mengusahakan tanah itu; ${ }^{6}$ tetapi ada kabut naik ke atas dari bumi dan membasahi seluruh permukaan bumi itu $-{ }^{7}$ ketika itulah TUHAN Allah membentuk manusia itu dari debu tanah dan menghembuskan nafas hidup ke dalam hidungnya;

Ada upaya untuk mengharmoniskan urutan penciptaan dari kedua narasi ini, beberapa bahkan membuat tanda khusus dalam penjemahannya. LAI membubuhkan tanda (-) yang mengapit ayat 5 dan 6, walaupun dalam teks aslinya tidak ada. Demikian pula pembacaan berikutnya dalam Kejadian 2:8, barulah dikisahkan Allah yang membuat taman di Eden di sebelah timur. Jadi berdasarkan urutan penciptaan dalam Kejadian 2:4a-25, justru manusia dicipta lebih dahulu daripada tumbuhan. Dalam mengharmoniskan masalah urutan penciptaan ini, NIV menambahkan terjemahan dari kata kerja dalam Kejadian 2:8 sebagai bentuk pluperfect sehingga menjadi kata "had planted" sehingga memberi kesan bahwa taman ini dicipta lebih dahulu daripada Adam.

34. Kejadian 2:4b-7 (TB-LAI). 
Pada sisi yang lain, ketika kedua peristiwa penciptaan itu dilihat dalam perspektif literer, maka permasalahan harmonisasi urutan tidak menjadi sebuah kontradiksi. Hal ini pun diungkapkan oleh Kline, bahwa urutan bukan menjadi fokus, melalui pernyataannya: "account has been shaped, not by a concern to satisfy our curiosity regarding sequence or chronology, but by predominately theological and literary concerns." 35 Kedua bagian narasi tersebut bermaksud untuk mengajarkan pembacanya tentang Allah, Sang Pencipta alam semesta. Maksud dari kedua bagian itu adalah sebagai suatu cara sastra untuk memberikan narasi tentang natur Allah, manusia dan alam semesta. Narasi itu bukan bermaksud untuk menjelaskan tentang bagaimana proses Allah mencipta manusia dan isi dunia, termasuk di dalamnya proses urutan hari secara harfiah dalam penciptaan. Dengan demikian proses dalam penciptaan bukan menjadi penekanan dalam kedua bagian narasi ini (Kej. 1:1-2:4a dan Kej. 2:4b-25). Dengan kata lain, teks Alkitab tidak memberitahukan dan menekankan kepada pembaca atau penerimanya bagaimana proses Allah mencipta isi dunia, yang mungkin akan lebih memuaskan ketika sains modern mencoba untuk menjelaskan detail prosesnya.

\section{Fokus yang Ditekankan dalam Kejadian 1-2}

Pencermatan atas penggunaan bahasa figuratif dan urutan narasi penciptaan menunjukkan bahwa penulis kitab Kejadian tidak

35. Meredith G. Kline, "The Framework View," dalam The Genesis Debates (Mission Viejo: Crux, 2001), 217. 
tertarik untuk memberikan detail proses penciptaan. Jika bukan untuk memberitahukan detail proses penciptaan, lalu apa yang menjadi fokus yang ditekankan dalam Kejadian 1-2? Kejadian 1-2 memberi klaim yang sangat jelas dalam hal ini, bahwa Allah adalah Sang Pencipta yang memberi kehidupan kepada manusia dan alam semesta. Selanjutnya Kejadian 1-2 juga menggambarkan Allah, Sang Pencipta yang jauh lebih tinggi dari para dewa yang diyakini bangsa Ancient Near East (ANE). ${ }^{36}$

Kejadian 1-2 juga berbicara tentang natur manusia. Hal yang berkembang dalam perdebatan tentang manusia seringkali menajam kepada asal usul manusia yang dikaitkan dengan teori evolusi. Kendati demikian pengamatan yang cermat atas narasi kitab tidak bermaksud untuk menjawab isu-isu perdebatan soal teori evolusi modern. Fokus atau maksud dari teks Alkitab adalah menekankan tentang natur manusia dalam relasinya dengan Allah dan sesamanya. Dalam pembahasan artikel di atas telah ditekankan bahwa penciptaan Adam dan Hawa adalah berbicara tentang natur relasinya, baik antara manusia dengan Allah maupun dengan sesamanya. Adam digambarkan sebagai ciptaan yang dibentuk dari debu tanah, namun juga diberikan napas dari Allah (Kej. 2:7). Hal ini menekankan bahwa, pada satu sisi manusia adalah bagian dari ciptaan, tetapi pada sisi lain manusia juga diberikan suatu relasi khusus dengan Allah, di mana natur spesifik ini tidak diberikan

36. Bruce K. Waltke, "The Creation Account in Genesis 1:1-3, Part IV: The Theology of Genesis 1," Bibliotheca Sacra 132 (Okt.-Des. 1975), 332. 
kepada binatang ataupun ciptaan yang lain. Demikian pula bahasa figuratif ketika Hawa dicipta dari tulang rusuk Adam menekankan suatu natur khusus, persamaan derajatnya dan relasi mutualismenya.

Kejadian 1-2 juga memberikan pengajaran yang penting terkait dengan pekerjaan dan Sabat. Dalam pendekatan literer, juga digambarkan karya kreatif Allah yang melakukan pekerjaan penciptaan selama enam hari dan berhenti pada hari ketujuh. Para pembaca di zaman kuno saat itu, membaca narasi Kejadian dan menjadikannya model bagaimana mereka harus bekerja enam hari lamanya dan menguduskan hari sabat. Averbeck dalam hal ini menyatakan bahwa:

The Gen 1 account describes it as a seven-day process because the creation of the cosmos was God's work, and this was God's work week, so to speak. Thus, the seven-day structure is an analogy that derives from and reinforce the regular pattern of the work week that God was so concern the Israelite adhere to: work six days and rest on the seventh (Exod 20:11; 23:12; 31:12-17; 35:1-3; Deut 5:12-15). ${ }^{37}$

Lebih lanjut lagi, narasi kedua (Kej. 2:4b-25) menggambarkan Adam yang diletakkan dalam taman untuk mengelola dan mengusahakannya. Demikian pula dengan Hawa yang dicipta bagi Adam sebagai penolong untuk melakukan suatu karya dan bekerjasama satu sama lain. Dalam hal ini, pekerjaan dapat dilihat

37. Richard E. Averbeck, The Future of Biblical Archeology: Reassessing Methodologies and Assumptions. ed. Mark J. Boda dan Jamie R. Novotny (Muster: Ugarit-Verlag, 2010), 8. 
sebagai tugas mulia dan bukan kutuk. Ketika manusia di zaman berikutnya mengalami kesulitan dan frustrasi dalam ladang pekerjaannya adalah tidak terlepas dari narasi Kejadian 3, yang mengisahkan Kejatuhan Adam dan kutuk atas tanah yang dikelolanya.

Demikian pula Kejadian 2 menggambarkan perkawinan sebagai sesuatu yang kudus dan yang Allah inisiasikan. Perkawinan sering disalahartikan sebagai akibat yang terjadi setelah kejatuhan manusia. Padahal Kejadian 2 dengan jelas menyatakan bahwa Allah telah mengadakan dan mengesahkan pernikahan sebelum manusia jatuh dalam dosa. Allah sendirilah yang berkata "adalah tidak baik jika lakilaki seorang diri saja" (Kej. 2:18), sehingga Allah menciptakan penolong yang lain, penolong yang sepadan dengan dia. Kata penolong adalah bukan untuk menunjukkan subordinasi, sebagaimana dipahami wanita hanya sebagai pelayan atau asisten. Demikian pula frasa "menjadi satu daging" adalah sebuah idiom yang menggambarkan hubungan seksual dan sekaligus juga mengingatkan pembacanya bahwa seksualitas adalah bukan sebuah produk yang terjadi oleh karena kejatuhan manusia, tetapi sebagai pemberian indah dari Allah. Dengan demikian Kejadian 1-2 menyajikan pengajaran yang begitu kaya tentang Allah, natur dan relasi manusia serta alam semesta. 


\section{Kesimpulan}

Ada banyak hal yang tetap menjadi misteri ketika mendiskusikan tentang bagaimana proses penciptaan manusia dan kosmos terjadi. Narasi penciptaan dalam Alkitab memang bukan bermaksud untuk menjelaskan proses scientific bagaimana manusia dan kosmos dijadikan. Oleh karenanya seorang pembaca narasi Alkitab perlu mencermati apa yang memang dimaksudkan dan ditekankan oleh penulis teks Alkitab. Peristiwa penciptaan dapat dilihat sebagai suatu yang historis, walaupun digambarkan secara kuat dalam bahasa figuratif. Penulis narasi Kejadian memberikan kode atau sinyal, yakni formula toledoth (i) dan dan penggunaan waw-consecutive untuk menunjukkan kontinuitas dari Kejadian 1-2 dan Kejadian pasal berikutnya yang menunjukkan bahwa kitab Kejadian ini secara keseluruhan menekankan aspek historisitas. Dalam hal ini Kejadian 1-2 memberitahukan kepada pembacanya tentang peristiwa yang sungguh-sungguh terjadi di masa lampau. Hanya saja memang tidak dapat dipungkiri bahwa Kejadian 1-2 bukan sebuah karya sejarah murni.

Hal yang tidak dapat dipungkiri juga adalah kuatnya penggunaan bahasa figuratif, dan ketidakurutan di antara kedua narasi penciptaan (Kej. 1:1-2:4a dan Kej. 2:4b-25) yang memberi argumentasi bahwa peristiwa penciptaan tidak dapat dilihat sebagai gambaran presisi dari proses penciptaan. Kendati demikian berdasarkan semua pertimbangan yang telah dikupas dalam artikel ini, maka Kejadian 1-2 dapat dilihat sebagai sejarah yang bersifat 
teologis (theological history). Penekanan sejarah yang bersifat teologis (theological history) terhadap narasi Kejadian 1-2 adalah bahwa teks tersebut bermaksud menekankan Allah sebagai Sang Pencipta manusia dan alam semesta, yakni Allah yang berkuasa untuk memberi eksistensi kepada segala sesuatu di alam semesta dan umat manusia.

\section{Daftar Pustaka}

Arnold, Bill T., dan John H. Choi. A Guide to Biblical Hebrew Syntax. Cambridge: Cambridge University Press, 2003.

Averbeck, Richard E. Giving the Sense: Understanding and Using Old Testament Historical Text. Ed. David Howard, Jr. dan Michael A. Grisanti. Grand Rapids: Kregel, 2003. . The Future of Biblical Archeology: Reassessing Methodologies abd Assumptions. Ed. Mark J. Boda dan Jamie R. Novotny. Munster: Ugarit-Verlag, 2010.

Beall, Todd S. Coming to Grips with Genesis: Biblical Authority and the Age of the Earth. Ed. Terry Mortenson dan Thane Ury. Green Forest: Master, 2008.

Blocher, Henri. In the Beginning: The Opening Chapters of Genesis. Leicester: InterVarsity, 1984.

Borg, Marcus J. The Heart of Christianity: Rediscovering a Life of Faith. San Francisco: Harper Collins, 2003.

Brueggeman, Walter. Genesis: A Bible Commentary for Teaching and Preaching. Atlanta: John Knox, 1982.

Carlson, Richard F., dan Tremper Longman III, Science, Creation, and the Bible: Reconciling Rival Theories of Origin. Downers Grove: IVP Academic, 2010.

Coats, George W. Genesis with an Introduction to Narrative Literature. Grand Rapids: Eerdmans. 1983.

Collins, C. John. Did Adam and Eve Really Exist? Who They Were and Why You Should Care. Wheaton: Crossway 2011. . Genesis 1-4: A Linguistic, Literary and Theological Commentary. Phillipsburg: P\&R, 2006. 
Cunningham, Conor. Darwin's Pious Idea: Why the Ultra-Darwinist and Creationists Both Get It Wrong. Grand Rapids: Eerdmans, 2010.

Daryl, Charles, J. ed. Reading Genesis 1-2: An Evangelical Conversation. Peabody: Hendrickson, 2013.

Enns, Peter. Inspiration and Incarnation. Grand Rapids: Baker, 2005. . The Evolution of Adam. Grand Rapids: Brazos, 2012.

Fee, Gordon D., dan Douglas Stuart. How to Read The Bible for All Its Worth. Grand Rapids: Zondervan, 2003

Geller, Markham J., dan Mineke Schipper. Imagining Creation. Leiden: Brill, 2008.

Gesenius, Wilhelm. Gesenius' Hebrew Grammar, ed. Ke-2 bahasa Inggris, Oxford: Clarendon, 1910.

Gunkel, Hermann. The Legends of Genesis. Eugene: Wipf \& Stock, 2003.

Hamilton, Victor P. The Book of Genesis: Chapters 1-17. NICOT. Grand Rapids: Eerdmans, 1990.

Howell, Kenneth J. Natural and Scripture in the Abrahamic Religion: Up to1700, vol. 1. Ed. J. Van Der Meer dan S. Mandelbrote. Leiden: Brill, 2008.

Kaiser Jr., Walter C. New Perspectives on the Old Testament. Ed. J. Barton Payne. Waco: Word, 1970.

Kaiser Jr., Walter C. The Old Testament Documents: Are They Reliable and Relevant? Downers Grove: InterVarsity, 2001.

Kline, Meredith G. The Genesis Debates. Mission Viejo: Crux, 2001. Longman III, Tremper. A Biblical History of Israel. Louisville: Westminster John Knox, 2003. . Foundations of Contemporary Interpretation. Ed. Moises Silva. Grand Rapids: Zondervan, 1996. . Reading the Bible with Heart and Mind. Colorado Springs, CO: NavPress, 1997.

Powell, Mark Allan. What is Narrative Criticism? Minneapolis: Fortress, 1990.

Sailhamer, John. The Pentateuch as Narrative. Grand Rapids: Zondervan, 1992. 
Sparks, Kenton L. God's Word in Human Words: An Evangelical Appropriation of Critical Biblical Scholarship. Grand Rapids: Baker Academic, 2008.

Waltke, Bruce K., dan Michael O'Connor. An Introduction to Biblical Hebrew Syntax. Winona Lake: Eisenbrauns, 1990.

Waltke, Bruce. Genesis: A Commentary. Grand Rapids: Zondervan, 2001.

Walton, John H., dan N.T. Wright. The Lost World of Adam and Eve: Genesis 2-3 and the Human Origins Debate. Downers Grove: IVP Academic, 2015.

Walton, John H. Lost World of Genesis One: Ancient Cosmology and the Origins Debate. Downers Grove: InterVarsity, 2009.

Wenham, Gordon Genesis 1-15. WBC 1. Waco, TX: Word, 1987.

Westermann, Claus. Genesis 1-11: A Commentary. Minneapolis: Augsburg, 1984.

Jurnal:

Waltke, Bruce K. "The Creation Account in Genesis 1:1-3, Part IV: The Theology of Genesis 1," Bibliotheca Sacra 132 (Oct.-Dec. 1975):25-36.

\section{Website:}

https://zondervanacademic.com/blog/genesis-1/ diakses 25 Februari 2019. 